\title{
NOTAS SOBRE O COMPLIANCE NO DIREITO BRASILEIRO
}

\section{Milena Donato Oliva ${ }^{1}$ \\ Rodrigo da Guia Silva ${ }^{2}$}

\section{Resumo}

O escopo central do presente estudo consiste na investigação dos efeitos jurídicos do compliance no direito brasileiro. Examinam-se, nesse sentido, as principais decisões judiciais e as principais normas que tratam do compliance, seja a título de incentivo, seja como mandamento legal. Além disso, analisa-se o crescimento da importância atribuída pelos agentes econômicos ao compliance em razão das vantagens que este propicia para a inserção e valorização da empresa no mercado. O texto também examina o tratamento da matéria pelo tribunais, que têm cada vez mais se utilizado da noção de compliance como parâmetro interpretativo para a resolução de questões as mais variadas envolvendo a atividade empresarial. Por fim, investiga-se a repercussão da adoção de programas de integridade no âmbito das sanções administrativas aplicáveis às pessoas jurídicas.

Palavras-chave: Compliance; Programas de integridade; Autorregulação; Autovigilância; Responsabilidade administrativa das pessoas jurídicas.

\footnotetext{
${ }^{1}$ Professora Adjunta de Direito Civil e do Consumidor da Universidade do Estado do Rio de Janeiro (UERJ). Doutora e Mestre em Direito Civil pela UERJ. Secretária Geral do Instituto Brasileiro de Direito Civil (IBDCivil) e Membro do Comitê Brasileiro da Association Henri Capitant des Amis de la Culture Juridique Française (AHC-Brasil). Advogada Sócia do Escritório Gustavo Tepedino Advogados.E-mail: mdo@tepedino.adv.br

${ }^{2}$ Doutorando e Mestre em Direito Civil pela Universidade do Estado do Rio de Janeiro (UERJ). Membro do Instituto Brasileiro de Direito Civil (IBDCivil) e do Comitê Brasileiro da Association Henri Capitant des Amis de la Culture Juridique Française (AHC-Brasil).E-mail: rodrigo.daguiasilva@gmail.com
} 


\section{INTRODUÇÃO}

A gradual - e crescente - absorção do compliance pelo direito positivo brasileiro tem ocorrido por meio de normas específicas, sem que haja uma sistematização legislativa, o que demanda esforço doutrinário para a apreensão global do instituto. Nesse contexto, o presente estudo busca, a partir do desenvolvimento recente do compliance em variados segmentos da disciplina jurídica brasileira, abordá-lo de forma sistemática, inserindo-o no ordenamento como um todo.

O texto aborda alguns dos principais efeitos jurídicos do compliance no sistema brasileiro, que vão desde o regular exercício de certas atividades econômicas até a obtenção de autênticas vantagens em matéria de responsabilização administrativa das pessoas jurídicas, em manifestação eloquente da função promocional do direito. Além disso, o compliance também apresenta impactos positivos para a imagem e a inserção da pessoa jurídica no mercado, haja vista que a adoção de programas de integridade desperta confiança nos seus parceiros comerciais, consumidores, funcionários, colaboradores e todos aqueles que com ela travam algum tipo de relação jurídica.

Inicialmente, investiga-se o conceito de compliance e a crescente atribuição de efeitos jurídicos pelo direito brasileiro, seja por força da atuação jurisprudencial, seja por força da sua positivação pelo legislador. Na sequência, examina-se a possível relação entre os mecanismos de compliance e a difusão das proposições teóricas defensoras da função preventiva da responsabilidade civil. Ademais, são objeto de análise as principais vantagens do compliance, sua repercussão no direito privado e a relevância que lhe é atribuída no âmbito da responsabilização administrativa das pessoas jurídicas. Espera-se, a partir deste estudo, demonstrar os potenciais do compliance para o incentivo a comportamentos social e eticamente desejados, em expressão da função promocional do direito.

\section{CONCEITO DE COMPLIANCE E SUA GRADUAL INCORPORAÇÃO PELO DIREITO BRASILEIRO}

A noção de compliance ${ }^{3}$ envolve o estabelecimento de mecanismos de autorregulação e

\footnotetext{
3 “( ... ) a origem do Programa de Conformidade decorre da expressão inglesa to comply, ou seja, 'agir de acordo com', e, portanto, está relacionado a qualquer tipo de regramento, regulação ou norma interna à uma organização pública ou privada ( ...)” (AUGUSTO, Naiara Czarnobai, Compliance corporativo. In: JOTA. Acesso em 01.04.2018). V., ainda, BLOK, Marcella. Compliance e governança corporativa. Rio de Janeiro: Freitas Bastos, 2018, p. 310.
} 
autorresponsabilidade pelas pessoas jurídicas. ${ }^{4}$ Quando se pensa em compliance, se reconduz imediatamente à ideia de autovigilância. ${ }^{5}$ Estrutura-se o ambiente corporativo a partir da adoção de normas de conduta que devem ser por todos acatadas, com particular destaque para a necessidade de comprometimento da alta administração em assegurar a efetividade do programa de compliance. ${ }^{6}$

Estipulam-se normas de conduta a serem seguidas, de maneira a se garantir o respeito à legalidade, à transparência, bem como a ausência de conivência com qualquer tipo de infração ou ilícito praticados pelos funcionários ou representantes da sociedade. Cuida-se da adoção de sistemas para assegurar o bom funcionamento do ambiente corporativo à luz não apenas das políticas internas de cada sociedade, como também das normas legais em vigor. ${ }^{7}$ De acordo com a definição constante do "Guia Programas de Compliancé, editado pelo Conselho Administrativo de Defesa Econômica (CADE):

Compliance é um conjunto de medidas internas que permite prevenir ou minimizar os riscos de violação às leis decorrentes de atividade praticada por um agente econômico e de qualquer um de seus sócios ou colaboradores. Por meio dos programas de compliance, os agentes reforçam seu compromisso com os valores e objetivos ali explicitados, primordialmente com o cumprimento da legislação. Esse objetivo é bastante ambicioso e por isso mesmo ele requer não apenas a elaboração de uma série de procedimentos, mas também (e principalmente) uma mudança na cultura corporativa. O programa de compliance terá resultados positivos quando conseguir incutir nos colaboradores a importância em fazer a coisa certa. ${ }^{8}$

\footnotetext{
4 "A autorregulação é essencial, portanto, para a construção de uma cultura de respeito à legalidade e à ética, uma vez que os incentivos para o cumprimento da lei passam a ser internos e desenvolvidos pela sociedade em lugar de serem externos e impostos pelo Estado" (FRAZÃO, Ana. Programas de compliance e critérios de responsabilização de pessoas jurídicas por ilícitos administrativos. In: ROSSETTI, Maristela Abla; PITTA, Andre Grunspun (Coords.). Governança corporativa: avanços e retrocessos. São Paulo: Quartier Latin, 2017, pp. 43-44). V., ainda, RILEY, Anne; SOKOL, D. Daniel. Rethinkg Compliance. Journal of Antitrust Enforcement, vol. 3, n. 1, abr./2015, item III; SILVEIRA, Renato de Mello Jorge. Compliancee direito penal na era pós-Lava Jato. Revista dos Tribunais, vol. 979, mai./2017, item 3; RIOS, Rodrigo Sánchez; ANTONIETTO, Caio. Criminal compliance - prevenção e minimização de riscos na gestão da atividade empresarial. Revista Brasileira de Ciências Criminais, vol. 114, mai.-jun./2015, item 2; SARCEDO, Leandro. Compliance e responsabilidade penal da pessoa jurídica: construção de um novo modelo de imputação, baseado na culpabilidade corporativa. Tese de doutorado. Universidade do Estado de São Paulo. São Paulo, 2014, pp. 16 ess.

${ }^{5}$ Nesse sentido, v. SARCEDO, Leandro. Compliance e responsabilidade penal da pessoa jurídica, cit., pp. 49 e ss. e SOUZA, Artur de Brito Gueiros; JAPIASSÚ, Carlos Eduardo Adriano. Criminologia e delinquência empresarial: da cultura criminógena à cultura do compliance. Quaestio Iuris, vol. 19, n. 2, 2017, p. 1033.

6 "Consequentemente, o compliancereforça a dimensão organizacional do dever de diligência, a fim de que controladores e administradores estruturem a organização empresarial de forma compativel com as atividades da companhia e com o risco por ela assumido. Para isso, torna-se necessário criar adequados sistemas de vigilância, supervisão e investigação sobre as atividades da sociedade, de modo a assegurar o respeito à obrigaç̣̂es legais e possibilitar a intervenç̧ão adequada diante da identificação de problemas e ameaças. Não é sem razão que um aspecto fundamental dos programas de complianceé a necessidade de comprometimento da alta administraç̧āo" (FRAZÃO, Ana. Dever de diligência: novas perspectivas em face de programas de compliance de atingimento de metas. In: JOTA. Acesso em 01.04.2018).

${ }^{7}$ GUARAGNI, Fábio André. Princípio da confiança no direito penal como argumento em favor de órgãos empresariais em posição de comando e compliance: relações e possibilidades. In: GUARAGNI, Fábio André; BUSATO, Paulo César (Coords.). Compliance e direito penal. São Paulo: Atlas, 2015, p. 74.

8 Fonte: http://www.cade.gov.br/acesso-a-informacao/publicacoes-institucionais/guias_do_Cade/guia-compliance-versaooficial.pdf. Acesso em 22.04.2018 às 17h. V. tb. a lição de Ana Frazão: "Compliance diz respeito ao conjunto de ações a serem
} 
Pertinente, ainda, a conceituação extraída do Decreto $n^{\circ} 8.420 / 2015$, que regulamenta a Lei Anticorrupção (Lei no 12.846/2013):

Art. 41. Para fins do disposto neste Decreto, programa de integridade consiste, no âmbito de uma pessoa jurídica, no conjunto de mecanismos e procedimentos internos de integridade, auditoria e incentivo à denúncia de irregularidades e na aplicação efetiva de códigos de ética e de conduta, políticas e diretrizes com objetivo de detectar e sanar desvios, fraudes, irregularidades e atos ilícitos praticados contra a administração pública, nacional ou estrangeira. Parágrafo único. O programa de integridade deve ser estruturado, aplicado e atualizado de acordo com as características e riscos atuais das atividades de cada pessoa jurídica, a qual por sua vez deve garantir o constante aprimoramento e adaptação do referido programa, visando garantir sua efetividade.

Destaque-se, a propósito, que não há um único modelo de compliance que possa ser adotado indistintamente por todas as pessoas jurídicas. Justamente por se tratar de sistema de prevenção de riscos e de respeito à legalidade, precisa se adequar à concreta atividade empreendida pela corporação e aos riscos e à regulamentação que lhe são próprios. Por outras palavras, o programa de integridade deve se adaptar às especificidades de cada pessoa jurídica e demanda permanente análise de riscos e verificação das normas jurídicas aplicáveis. Nessa direção, cada sistema a ser implementado tem amplo espaço de conformação pela entidade, que pode instituir o modelo de compliance que melhor se adeque às suas particularidades, desde que seja efetivo e atenda ao objetivo primordial de efetivamente evitar infrações à ordem jurídica e de, uma vez verificadas, contribuir para sua pronta reparação e para o retorno ao estado de normalidade.

Sem embargo da diversidade dos programas de compliance adotados por cada pessoa jurídica, podem-se apontar alguns parâmetros gerais que concorrem para a análise da sua robustez, tais como: comprometimento da alta administração; recursos adequados às particularidades da organização (porte, mercado de atuação etc.); autonomia e independência do órgão ou funcionário responsável pela implementação dos programas de compliance; análise contínua dos riscos aos quais a entidade está exposta; realização de treinamento e instrução dos colaboradores para a implementação da política de integridade da pessoa jurídica, bem como para a utilização de canais de denúncia; monitoramento contínuo e efetivo do programa; documentação das iniciativas relacionadas ao compliance; aplicação de punições internas nas hipóteses de infração às disposições legais e ao Código de Ética da corporação; revisão e adaptação do programa ao longo do tempo e em atenção à modificação das atividades da pessoa jurídica. ${ }^{9}$

adotadas no ambiente corporativo para que se reforce a anuência da empresa à legislação vigente, de modo a prevenir a ocorrência de infrações ou, já tendo ocorrido o ilícito, propiciar o imediato retorno ao contexto de normalidade e legalidade" (FRAZÃO, Ana. Programas de compliancee critérios de responsabilização de pessoas jurídicas por ilícitos administrativos, cit., p. 42).

9 Tal listagem de parâmetros foi extraída do "Guia Programas de Compliance" do CADE para a identificação de programas robustos de compliance concorrencial (CADE. Guia Programas de Compliance, pp. 15-29. Fonte: http://www.cade.gov.br/acesso-a-informacao/publicacoes-institucionais/guias_do_Cade/guia-compliance-versao-oficial.pdf. 
É comum se invocar como importante marco internacional do compliance as U.S. Sentencing Guidelines de $1991 .{ }^{10}$ No Brasil, sobretudo a partir da transição da década de 1990 para a primeira década do século XXI, verificou-se o progressivo reconhecimento legislativo da relevância do compliance. Nesse sentido, o compliance passou a ser exigência da Comissão de Valores Mobiliários (CVM) e do Banco Central do Brasil (BACEN) para a atuação em certas atividades. ${ }^{11}$ Além disso, o compliancepassou a ser considerado parâmetro de dosimetria das penas administrativas impostas às pessoas jurídicas por ilícitos corporativos previstos na Lei Anticorrupção. Também passou a ser exigido das empresas públicas, sociedades de economia mista e de suas subsidiárias a instituição de programa de compliance.

Dessa forma, no Brasil, assiste-se, progressivamente, à atribuição de efeitos jurídicos explícitos ao compliance, que é tratado na legislação como: (i) prática incentivada por meio da previsão legal de consequências favoráveis ( $v \cdot g$. dosimetria da pena) ${ }^{12}$ ou (ii) obrigação legal em sentido estrito (como no caso da imposição, pela legislação federal, da obrigatoriedade de as empresas estatais adotarem programas de compliance). ${ }^{13}$ Além disso,

Acesso em 22.04.2018 às 17h). V. tb. art. 42 do Decreto 8.420/2015 e o Programa de Integridade: Diretrizes para Empresas Privadas elaborado pela Controladoria-Geral da União (CGU).

10 “Nos EUA, a base para a implementação dos 'Programas de Compliance' é estabelecida pelas 'Federal Sentencing Guidelines for Organizations' ('Guidelines'), emitidas pela 'U.S. Sentencing Comission'. Essas Guidelines configuram a compilação das orientaçōes dadas aos juízes norte-americanos para julgamento de crimes federais praticados por empresas, assinalando diretrizes a serem seguidas. As disposições a respeito passaram a vigorar em 10 de novembro de 1991 (...)" (MARTINEZ, Maria Beatriz. Programas de compliance e a defesa da concorrência: perspectivas para o Brasil. Revista do IBRAC - Direito da Concorrência, Consumo e Comércio Internacional, vol. 12, jan./2005, item 2.1.1); "Em 1991, as U.S. Sentencing Comission's Guidelines proveram às companhias intensos incentivos financeiros para a adoção de programas efetivos de ética e compliance. Desde então, o compliance se tornou um grande negócio" (STUCKE, Maurice E. In Search of Effective Ethics \& Compliance Programs. The Journal of Corporation Law, vol. 39, 2014, p. 770. Tradução livre do original). As U.S. Sentencing Guidelines consistem fundamentalmente em diretrizes gerais para a prolação de sentenças contra crimes federais, com a previsão de vantagens aos agentes que hajam adotado programas efetivos de compliance. Aludidas vantagens financeiras consistiriam, principalmente, na expressiva redução das penalidades às pessoas jurídicas condenadas que houvessem adotado programas de compliance, conforme se depreende do relato de KRAWIEC, Kimberly D. Cosmetic Compliance and the Failure of Negotiated Governance. Washington University Law Quarterly, vol. 81, 2003, p. 498. V. tb. HENNING, Peter J. Be Careful What You Wish For: Thoughts on a Compliance Defense Under the Foreign Corrupt Practices Act. Ohio State Law Journal, vol. 73, 2012, pp. 896-897; e WOUTERS, Jan; RYNGAERT, Cedric; CLOOTS, Ann Sofie. The International Legal Framework Against Corruption: Achievements and Challenges. Melbourne Journal of International Law, vol. 14, 2013, p. 76. Para um relato da evolução do compliance, também na década de 1990, no âmbito da experiência europeia, v. MARTINEZ, Maria Beatriz. Programas de compliance e a defesa da concorrência, cit., item 2.1.2.

11 "O termo compliance estabeleceu-se, nos últimos anos, como tema da moda no direito penal. Contudo, apesar de ter ganhado crescente atenção da doutrina, não há, ainda, consenso sobre seu tratamento e suas consequências no âmbito criminal. Sua aplicação nasceu no campo financeiro, no qual, no Brasil, conta, por exemplo, com regras bastante específicas determinadas pelo Banco Central, mas hoje acabou por expandir-se por diversos outros âmbitos da atividade empresarial. Assim, o assunto passou a ocupar um espaço importante de reflexão no campo do direito penal econômico" (COSTA, Helena Regina Lobo da; ARAÚJO, Marina Pinhão Coelho. compliance e o julgamento da APN 470. Revista Brasileira de Ciências Criminais, vol. 106, 2014. Acesso pela Revista dos Tribunais Online, em 02.04.2018).

12 "Embora incontroversa a relevância da Lei no 12.846/2013 (Lei Anticorrupção), a mesma não é impositiva, mas contém, somente, a recomendação de condutas para fins de amenização das sanções penais, civis e administrativas" (TJSP, 1ª C.R.D.E., AI 2065937-30.2017.8.26.0000, Rel. Des. Alexandre Lazzarini, julg. 23.8.2017).

${ }^{13}$ V. Lei $13.303 / 2016$, arts. $6^{\circ}$ e $9^{\circ}$. 
observa-se gradual expansão, por parte da jurisprudência, na utilização da noção de compliance como parâmetro interpretativo para a resolução de questões as mais variadas envolvendo a atividade empresarial e sua regulação pelo direito privado (v. item 5, infra).

\section{PRINCIPAIS PREVISÕES NORMATIVAS DO COMPLIANCE}

Em primeiro lugar, destaque-se a Lei no 9.613/1998 (com relevantes alterações promovidas pela Lei no 12.683/2012),,$^{14}$ que dispõe sobre os crimes de "lavagem" ou ocultação de bens, direitos e valores. ${ }^{15}$ Seus artigos $9^{\circ}, 10$ e 11 tratam, respectivamente, das pessoas sujeitas ao mecanismo de controle, da identificação dos clientes e da manutenção de registros e comunicação de operações financeiras suspeitas de irregularidades. ${ }^{16}$ Tais

\footnotetext{
${ }^{14}$ A redação originária do referido diploma legal já continha normas orientadas à promoção de uma cultura de integridade pelas instituições financeiras, tais como: identificar clientes e manter seu cadastro atualizado (art. 10, I); manter registro de toda transação superior ao limite fixado pela autoridade administrativa (art. 10, II); atender às requisições formuladas pelo Conselho de Controle de Atividades Financeiras do Ministério da Fazenda (arts. 10, III, e 14); dedicar especial atenção às operações que pudessem apresentar sérios indícios dos crimes previstos na lei (art. 11, I); comunicar às autoridades competentes as transações excedentes dos limites fixados pelas autoridades administrativas (art. 11, II, a). Nada obstante a previsão, na redação originária da lei, dessas e de outras normas relacionadas à promoção de uma cultura de integridade e de respeito à legalidade, observa-se que a Lei $n^{\circ}$ 12.683/2012 veio a tornar ainda mais explícito o dever de adoção de programas de compliance pelas instituições financeiras ao alterar a redação do inciso III do artigo 10 para estabelecer o seguinte: "Art. 10. As pessoas referidas no art. 9: (...) III - deverão adotar políticas, procedimentos e controles internos, compatíveis com seu porte e volume de operações, que lhes permitam atender ao disposto neste artigo e no art. 11, na forma disciplinada pelos órgãos competentes".

${ }^{15}$ A destacar a importância da Lei no 9.613/1998 na matéria, afirma-se: "No Brasil, a relevância dos programas de compliance no mundo jurídico-penal ganhou força com a edição da Lei 9.613/98 (Lei de Lavagem de Dinheiro). Porém, somente com as alterações desta, após a edição da Lei 12.863/12, e com a publicação da Lei 12.846/13 (Lei Anticorrupção) - que contém expressão de um direito sancionador judicial, com matizes de direito penal, conquanto não carregue o rol de garantias típico deste universo -, o tema passou definitivamente ao horizonte de estudo do direito penal econômico" (GUARAGNI, Fábio André; MARIA SOBRINHO, Fernando Martins. Compliance e crimes culposos: a categoria do risco proibido como ponto de um "encontro marcado". Quaestio Iuris, vol. 9, n. 1, 2016, p. 274).

${ }^{16}$ Lei no 9.613/1988: "Art. 9o Sujeitam-se às obrigações referidas nos arts. 10 e 11 as pessoas físicas e jurídicas que tenham, em caráter permanente ou eventual, como atividade principal ou acessória, cumulativamente ou não: I - a captação, intermediação e aplicação de recursos financeiros de terceiros, em moeda nacional ou estrangeira; II - a compra e venda de moeda estrangeira ou ouro como ativo financeiro ou instrumento cambial; III - a custódia, emissão, distribuição, liqüidação, negociação, intermediação ou administração de títulos ou valores mobiliários. (...)"; "Art. 10. As pessoas referidas no art. 9o: I - identificarão seus clientes e manterão cadastro atualizado, nos termos de instruções emanadas das autoridades competentes; II - manterão registro de toda transação em moeda nacional ou estrangeira, títulos e valores mobiliários, títulos de crédito, metais, ou qualquer ativo passível de ser convertido em dinheiro, que ultrapassar limite fixado pela autoridade competente e nos termos de instruções por esta expedidas; III - deverão adotar políticas, procedimentos e controles internos, compatíveis com seu porte e volume de operações, que lhes permitam atender ao disposto neste artigo e no art. 11, na forma disciplinada pelos órgãos competentes; IV - deverão cadastrar-se e manter seu cadastro atualizado no órgão regulador ou fiscalizador e, na falta deste, no Conselho de Controle de Atividades Financeiras (Coaf), na forma e condições por eles estabelecidas; V - deverão atender às requisições formuladas pelo Coaf na periodicidade, forma e condições por ele estabelecidas, cabendo-lhe preservar, nos termos da lei, o sigilo das informações prestadas. (...)"; "Art. 11. As pessoas referidas no art. 9o: I - dispensarão especial atenção às operações que, nos termos de instruções emanadas das autoridades competentes, possam constituir-se em sérios indícios dos crimes previstos nesta Lei, ou com eles relacionar-se; II - deverão comunicar ao Coaf, abstendo-se de dar ciência de tal ato a qualquer pessoa, inclusive àquela à qual se refira a informação, no prazo de 24 (vinte e quatro) horas, a proposta ou realização: a) de todas as transações referidas no inciso II do art. 10, acompanhadas da identificação de que trata o inciso I do mencionado artigo; e b) das operações referidas no inciso I; III
} 
dispositivos ilustram a absorção do complianceem caráter impositivo pelo direito brasileiro. ${ }^{17}$

Veja-se, ainda, a Resolução no 2.554/1998 do BACEN, cujo artigo 1º, caput, determinou “(...) às instituições financeiras e demais instituições autorizadas a funcionar pelo Banco Central do Brasil a implantação e a implementação de controles internos voltados para as atividades por elas desenvolvidas, seus sistemas de informações financeiras, operacionais e gerenciais e o cumprimento das normas legais e regulamentares a elas aplicáveis". ${ }^{18}$

Semelhante ordem de disposição foi estabelecida, no âmbito da regulação da concorrência, pela Secretaria de Direito Econômico (SDE) do Ministério da Justiça - Secretaria essa que veio a ser absorvida pelo Conselho Administrativo de Defesa Econômica nos termos da Lei no 12.529/2011. A extinta Secretaria editou a Portaria no 14/2004, a fim de definir diretrizes gerais para a elaboração de Programas de Prevenção de Infrações à Ordem Econômica (PPI) e estabelecer requisitos e condições para a emissão, pela SDE, do respectivo Certificado de Depósito. ${ }^{19}$

Na sequência, cumpre fazer menção à Lei Anticorrupção (Lei no 12.846/2013). Embora não contenha imposição expressa quanto à adoção de programas de compliance, estabelece a valoração positiva dessa conduta

\footnotetext{
- deverão comunicar ao órgão regulador ou fiscalizador da sua atividade ou, na sua falta, ao Coaf, na periodicidade, forma e condições por eles estabelecidas, a não ocorrência de propostas, transações ou operações passíveis de serem comunicadas nos termos do inciso II. $\mathbb{\$} 1^{\circ}$ As autoridades competentes, nas instruções referidas no inciso I deste artigo, elaborarão relação de operações que, por suas características, no que se refere às partes envolvidas, valores, forma de realização, instrumentos utilizados, ou pela falta de fundamento econômico ou legal, possam configurar a hipótese nele prevista. $\$ 2^{\circ}$ As comunicações de boa-fé, feitas na forma prevista neste artigo, não acarretarão responsabilidade civil ou administrativa. $\mathbb{\$} 3^{\circ} \mathrm{O}$ Coaf disponibilizará as comunicações recebidas com base no inciso II do caputaos respectivos órgãos responsáveis pela regulação ou fiscalização das pessoas a que se refere 0 art. $9^{0^{\prime \prime}}$.

${ }_{17}$ "Diga-se, aliás, que é essencial a colaboração das instituições financeiras nesse processo, a chamada compliance, diante da evidente impossibilidade de o Estado fiscalizar a tudo. A regra em exame guarda relação com o disposto nos arts. 10 e 11 da Lei n ${ }^{\circ}$ 9.613/98, que impõe às instituições arroladas em seu art. $9^{\circ}$ o dever de identificar os clientes e comunicar operações suspeitas de lavagem de dinheiro" (BALTAZAR JUNIOR, José Paulo. Sigilo bancário e privacidade. Porto Alegre: Livraria do Advogado, 2005, p.99).

${ }^{18} \mathrm{O} \ 1^{\circ}$ do mesmo dispositivo estabelece: "Os controles internos, independentemente do porte da instituição, devem ser efetivos e consistentes com a natureza, complexidade e risco das operações por ela realizadas".

${ }^{19} \mathrm{O}$ artigo $4^{\circ}$ da Portaria no $14 / 2004$ da SDE estabeleceu, entre outros requisitos do PPI, os seguintes: "(a) criação de padrões e procedimentos claros com relação à observância da legislação de defesa da concorrência por parte do quadro de funcionários do depositante; (b) indicação e qualificação de dirigente com autoridade para coordenar e supervisionar os objetivos propostos no PPI; (c) indicação do grau de delegação e fiscalização, pelos dirigentes do depositante, dos poderes de negociação, bem como de efetiva prestação de contas por parte dos funcionários responsáveis pelos contatos com os agentes dos mercados onde atua o depositante; e (d) mecanismos de disciplina eficientes para identificação e punição dos envolvidos com reais ou potenciais infrações à ordem econômica". Destaca-se, em doutrina, a relevância dos Programas de Prevenção de Infrações à Ordem Econômica (PPI) para a consolidação do compliance no âmbito concorrencial: "No Brasil, o 'Programa de Compliance' foi inserido formalmente no âmbito específico do direito da concorrência por meio da criação do PPI" (MARTINEZ, Maria Beatriz. Programas de compliance e a defesa da concorrência, cit,, item 3).
} 
por ocasião da dosimetria das sanções a serem impostas às pessoas jurídicas. ${ }^{20}$ A Lei Antitruste (Lei no 12.529/2011) não contém previsão semelhante, mas o Guia Programas de Compliance do Conselho Administrativo de Defesa Econômica - CADE estabelece que:

A adoção de um programa de compliance robusto, com medidas de controle de danos, que atenda aos requisitos expostos na seção III.2 acima, pode ser considerada evidência da boa-fé da organização infratora e da redução dos efeitos econômicos negativos da prática ilicita no mercado. Por conta disso, é possivel que o Tribunal enquadre o programa de compliance como (i) uma evidência de boa-fé e o configure como uma atenuante no cálculo da multa, reduzindo-a, ou como (ii) um critério a ser considerado quando do cálculo da contribuiç̧ão pecuniária, em eventual TCC a ser assinado pela organização, que poderia levar o percentual de desconto ao máximo permitido.

Destaque-se, ainda, o Decreto no 8.420/2015 (que regulamenta a Lei Anticorrupção), cujo artigo 42 especifica parâmetros para avaliação da existência e da efetividade do programa de integridade referido pelo artigo 70, VIII, da Lei Anticorrupção. Também vale mencionar o Programa de Integridade: Diretrizes para Empresas Privadas elaborado pela Controladoria-Geral da União (CGU), que estipula parâmetros a serem observados na instituição do compliance. ${ }^{21}$

A Lei das Estatais (Lei no 13.303/2016) estabelece, em seu artigo 60, a necessidade de o estatuto da empresa pública, da sociedade de economia mista e de suas subsidiárias "observar regras de governança corporativa, de transparência e de estruturas, práticas de gestão de riscos e de controle interno" ${ }^{22} \mathrm{O}$ artigo $9^{\circ}$, a seu turno, estipula que "a empresa pública e a sociedade de economia mista adotarão regras de estruturas e práticas de gestão de riscos e controle interno que abranjam: I - ação dos administradores e empregados, por meio da implementação cotidiana de práticas de controle interno; II - área responsável pela verificação de cumprimento de obrigações e de gestão de riscos; III - auditoria interna e Comitê de Auditoria Estatutário", determinando, ainda, a elaboração de e divulgação de Código de Conduta e Integridade $\left(\$ 1^{\circ}\right)$.

Também a Comissão de Valores Mobiliários (CVM), por meio da Instrução CVM no 586/2017, alterou a redação da Instrução CVM no 480/2009 - que dispõe sobre o registro de emissores de valores

\footnotetext{
${ }^{20}$ Art. $7^{\circ}$ da Lei 12.846/2013: "Serão levados em consideração na aplicação das sanções: VIII - a existência de mecanismos e procedimentos internos de integridade, auditoria e incentivo à denúncia de irregularidades e a aplicação efetiva de códigos de ética e de conduta no âmbito da pessoa jurídica; (...)".

21 "O conteúdo desta publicação tem por objetivo esclarecer o conceito de Programa de Integridade em consonância com a Lei no 12.846/2013 e suas regulamentaçōes e apresentar diretrizes que possam auxiliar as empresas a construir ou aperfeiçoar Programa dessa natureza. $\mathrm{O}$ documento é eminentemente orientativo e não possui, portanto, caráter normativo ou vinculante. As diretrizes descritas não criam direitos ou garantias, sejam eles relacionados a eventual análise de Programa de Integridade em processo de responsabilização com base na Lei no 12.846/2013 ou a qualquer outro processo ou procedimento nas esferas administrativa ou judicial" (https://www.cgu.gov.br/Publicacoes/etica-e-integridade/arquivos/programa-de-integridade-diretrizes-para-empresasprivadas.pdf). V. tb. Instrução Normativa Conjunta n. 01, de 10 de maio de 2016.
} 
mobiliários admitidos à negociação em mercados regulamentados de valores mobiliários - para estabelecer a obrigatoriedade de informar "se o emissor possui regras, políticas, procedimentos ou práticas voltadas para a prevenção, a detecção e remediação de fraudes e ilícitos praticados contra a administração pública" (item 5.4 do Anexo 24 - Conteúdo do Formulário de Referência). Além disso, a Instrução CVM no 558/2015 (alterada pela Instrução CVM no 593/2017) impõe, no que tange ao exercício profissional de administração de carteiras de valores mobiliários, exigências acerca da implementação de programas de compliance. ${ }^{23}$

A relevância do complianceé ressaltada pelo Regulamento do Novo Mercado vigente desde 02.01.2018, que estabelece: "A companhia deve implantar funções de compliance, controles internos e riscos corporativos, sendo vedada a acumulação com atividades operacionais" (art. 24); "A companhia deve elaborar e divulgar código de conduta aprovado pelo conselho de administração e aplicável a todos os empregados e administradores que contemple, no mínimo (...) II - as regras objetivas relacionadas à necessidade de compliance e conhecimento

${ }^{22}$ A análise da doutrina estrangeira revela que tal ordem de imposição do compliance a empresas estatais não configura propriamente uma peculiaridade da experiência brasileira. A título puramente ilustrativo, veja-se STUCKE, Maurice E. In Search of Effective Ethics \& Compliance Programs, cit., p. 770.

23 "Art. $4^{\circ}$. Para fins de obtenção e manutenção da autorização pela CVM, o administrador de carteiras de valores mobiliarios, pessoa jurídica, deve atender os seguintes requisitos: (...) IV - atribuir a responsabilidade pelo cumprimento de regras, politicas, procedimentos e controles internos e desta Instrução a um diretor estatutário; $₫ 3^{\circ}$ Os diretores responsáveis pela gestão de risco e pelo cumprimento de regras, politicas, procedimentos e controles internos e desta Instrução: I - devem exercer suas funções com independência; (...). Art. 14. O administrador de carteiras de valores mobiliários, pessoa jurídica, deve manter página na rede mundial de computadores com as seguintes informações atualizadas: (...) II - código de ética, de modo a concretizar os deveres do administrador previstos no art. 16 desta Instrução; (...) III - regras, procedimentos e descrição dos controles internos, elaborados para o cumprimento desta Instrução; (...) Art. 19. O administrador de carteiras de valores mobiliários, pessoa jurídica, deve garantir, por meio de controles internos adequados, o permanente atendimento às normas, politicas e regulamentaçoes vigentes, referentes às diversas modalidades de investimento, à própria atividade de administração de carteiras de valores mobiliários e aos padrões ético e profissional. Parágrafo único. Os controles internos devem ser efetivos e consistentes com a natureza, complexidade e risco das operaçoos realizadas. Art. 20. O administrador de carteiras de valores mobiliários, pessoa juridica, deve exercer suas atividades de forma a: I - assegurar que todos os profissionais que desempenhem funções ligadas à administração de carteiras de valores mobiliários atuem com imparcialidade e conheçam o código de ética e as normas aplicáveis, bem como as politicas previstas por esta Instrução e as disposições relativas a controles internos; e II - identificar, administrar e eliminar eventuais conflitos de interesses que possam afetar a imparcialidade das pessoas que desempenhem funções ligadas à administração de carteiras de valores mobiliarios. Parágrafo único. $\mathrm{O}$ administrador de carteiras de valores mobiliários, pessoa jurídica, deve desenvolver e implementar regras, procedimentos e controles internos, por escrito, com o objetivo de assegurar o cumprimento do disposto no caput e seus incisos. (...)”. Veja-se, ainda, a Instrução CVM n 505/2011 (que estabelece normas e procedimentos a serem observados nas operações realizadas com valores mobiliários em mercados regulamentados de valores mobiliarios), alterada pelas Instruções CVM n 526/2012 e n ${ }^{\circ} 581 / 2016$ : "Art. $3^{\circ}$ O intermediário deve adotar e implementar: I - regras adequadas e eficazes para o cumprimento do disposto na presente Instrução; e II - procedimentos e controles internos com o objetivo de verificar a implementação, aplicação e eficácia das regras mencionadas no inciso I. (...) $₫ 2^{\circ}$ São consideradas descumprimento do disposto nos incisos I e II do caput não apenas a inexistência ou insuficiência das regras, procedimentos e controles ali referidos, como também a sua não implementação ou a implementação inadequada para os fins previstos nesta Instrução. $\$ 3^{\circ}$ São evidências de implementação inadequada das regras, procedimentos e controle internos: I - a reiterada ocorrência de falhas; e II - a ausência de registro da aplicação da metodologia, de forma consistente e passivel de verificação. Art. $4^{\circ} \mathrm{O}$ intermediario deve indicar: I - um 
sobre a legislação e a regulamentação em vigor, em especial, às normas de proteção à informação sigilosa da companhia, combate à corrupção, além das políticas da companhia" (art. 31). ${ }^{24}$

A Lei no 7.753/2017 do Estado do Rio de Janeiro, cujo art. $1^{\circ}$ estabelece "a exigência do Programa de Integridade às empresas que celebrarem contrato, consórcio, convênio, concessão ou parceria público-privado com a administração pública direta, indireta e fundacional do Estado do Rio de Janeiro, cujos limites em valor sejam superiores ao da modalidade de licitação por concorrência, sendo R $1.500 .000,00$ (um milhão e quinhentos mil reais) para obras e serviços de engenharia e $\mathrm{R} \$ 650.000,00$ (seiscentos e cinquenta mil reais) para compras e serviços, mesmo que na forma de pregão eletrônico, e o prazo do contrato seja igual ou superior a 180 (cento e oitenta) dias". O artigo $4^{\circ}$ da lei estadual reproduz, em larga medida, os parâmetros de avaliação constantes do já referido Decreto no 8.420/2015.

Como se percebe das hipóteses mencionadas, as diversas normativas relegam a cada agente econômico a individualização das concretas medidas de compliance a serem adotadas. E nem poderia ser diferente, haja vista que os programas de compliance precisam ser adequados à realidade de cada corporação, ${ }^{25}$ observadas, evidentemente, as diretrizes gerais que devem existir em todo compliance, ${ }^{26}$ bem como as orientações constantes na legislação aplicável.

\section{AUTOVIGILÂNCIA, PREVENÇÃO E REPARAÇÃO DE ILICITOS COORPORATIVOS}

A adoção do compliance é cada vez mais essencial às pessoas jurídicas. Não apenas pelos incentivos legislativos ou por imposição legal, mas também porque o compliance atesta a seriedade do agente econômico e, com isso, viabiliza mais negócios e maior inserção no mercado.

\footnotetext{
diretor estatutário responsável pelo cumprimento das normas estabelecidas por esta Instrução; e II - um diretor estatutário responsável pela supervisão dos procedimentos e controles internos previstos no inciso II do caput do art. $3^{\circ}(. . .)^{\prime \prime}$.

${ }^{24}$ Fonte: http://www.bmfbovespa.com.br/pt_br/regulacao/regulamentos-e-manuais/\#item-2. Acesso 03.04.2018. Colhe-se da doutrina o relato de semelhante tendência de absorção do compliance pelo mercado financeiro no âmbito dos Estados Unidos da América: "Companhias listadas na Bolsa de Valores de Nova Iorque [New York Stock Exchange] e na NASDAQ devem possuir um código ético" (STUCKE, Maurice E. In Search of Effective Ethics \& Compliance Programs, cit, p. 771. Tradução livre).

25 "Um bom programa de compliance deve levar em conta os riscos específicos a que se submete cada empresa, que variam de acordo com seu porte, a posição de mercado, o setor em que atua, a complexidade da regulação, etc. Por isso, não é possível falar em um único modelo de programa de compliance (...). Assim, mesmo havendo relativo consenso quanto às diretrizes básicas dos programas de compliance, é bom ficar atento para o fato de que elas não comportam aplicação uniforme" (FRAZÃO, Ana. Cartilha sobre Compliance. No prelo. Original gentilmente cedido pela autora).

${ }^{26} \mathrm{~V}$, sobre os parâmetros para verificação da seriedade do programa de compliance adotado, Guia Programas de Compliance do CADE, pp. 15-29. Fonte: http://www.cade.gov.br/acesso-a-informacao/publicacoes-institucionais/guias_do_Cade/guiacompliance-versao-oficial.pdf. Acesso em 22.04.2018 às $17 \mathrm{~h}$; art. 42 do Decreto 8.420/2015 e o Programa de Integridade: Diretrizes para Empresas Privadas elaborado pela Controladoria-Geral da União (CGU).
} 
Nesse sentido, a exigência de programas de integridade não é apenas legislativa, mas também dos parceiros comerciais, consumidores, funcionários, colaboradores, na medida em que o compliance busca assegurar ambiente corporativo sério, saudável e comprometido com a legalidade. ${ }^{27}$ Não por acaso se reconhece que a adoção de programas efetivos de compliance pode produzir benefícios para muito além das sanções premiais previstas em lei, podendo gerar expressivas vantagens em aspectos como concorrência, atração dos consumidores e até o incremento do bem-estar dos colaboradores da pessoa jurídica. ${ }^{28} \mathrm{O}$ CADE, em seu Guia "Programas de Compliance", enumera algumas das vantagens da implementação do compliance: benefício reputacional; conscientização dos funcionários; redução de custos e contingências; identificação antecipada de problemas; e prevenção de riscos. ${ }^{29}$

Ao se levar em consideração especificamente a função de prevenção de riscos, indaga-se se haveria alguma aproximação entre a expansão do compliancee a difusão das proposições teóricas que buscam atribuir ao regime da responsabilidade civil papel preventivo em complemento ao reparatório.

Tem ganhado cada vez mais força o entendimento de que a responsabilidade civil também teria caráter punitivo, não se limitando à função indenizatória. ${ }^{30}$ Embora criticável aludido ponto de vista, ${ }^{31}$ aduz-se que o

\footnotetext{
${ }^{27}$ Em semelhante linha de sentido, v. RILEY, Anne; SOKOL, D. Daniel. Rethinkg Compliance, cit., item II.A.2.

28 "Além de evitar prejuízos, uma firma pode almejar uma cultura organizacional ética para o seu próprio bem, para uma vantagem competitiva estratégica, ou para evitar ser competitivamente prejudicada. Uma recente pesquisa de ética empresarial revelou que 'uma cultura baseada em valores não se afasta da alta performance, mas na verdade gera uma vantagem competitiva'. Uma cultura ética pode ajudar firmas a atrair e reter consumidores, investidores e empregados. Uma cultura ética pode aumentar a significação das tarefas dos empregados e o bem-estar (na medida em que os empregados extraem maior sentido moral dos seus trabalhos), o que pode aumentar a lucratividade. Ao sinalizar a ética e a confiabilidade da firma, um programa ético efetivo pode tornar a firma mais atrativa para potenciais adquirentes e joint venturers. Os esforços de compliance podem reduzir as preocupações da empresa adquirente sobre litigiosidade inesperada ou atividade ilegal inflar o valor da companhia alvo" (STUCKE, Maurice E. In Search of Effective Ethics \& Compliance Programs, cit., pp. 777-778. Tradução livre).

29 Fonte: http://www.cade.gov.br/acesso-a-informacao/publicacoes-institucionais/guias_do_Cade/guia-compliance-versaooficial.pdf. Acesso em 22.04.2018 às 17h. Em semelhante linha de sentido, afirma-se: "Um Compliance efetivo garante a identificação e a extinção de riscos financeiros, de segurança física e digital, trabalhistas, administrativos, fiscais e tributários, e, principalmente, afasta o desrespeito aos padrões éticos e morais previstos na Constituição Federal, legislação vigente e em normas internas" (AUGUSTO, Naiara Czarnobai. Compliance corporativo, cit.).

${ }^{30}$ Veja-se, ilustrativamente: "A indenização por danos morais possui tríplice função, a compensatória, para mitigar os danos sofridos pela vítima; a punitiva, para condenar o autor da prática do ato ilícito lesivo, e a preventiva, para dissuadir o cometimento de novos atos ilícitos. Ainda, o valor da indenização deverá ser fixado de forma compatível com a gravidade e a lesividade do ato ilícito e as circunstâncias pessoais dos envolvidos" (STJ, 4a T., REsp 1.440.721/GO, Rel. Min. Maria Isabel Gallotti, julg. 11.10.2016, DJe 11.11.2016); "A indenização por danos morais, ainda que tenha sido deferida medida liminar para a cobertura médica pleiteada, conserva a função pedagógico-punitiva de desestimular o ofensor a repetir a falta” (STJ, 3a T., AgInt no AREsp 862.868/CE, Rel. Min. Moura Ribeiro, julg. 16.6.2016, DJe 23.6.2016); "A fixação dos danos morais no patamar de R\$ 6.000,00 (seis mil reais) cumpre, no presente caso, a função pedagógico- punitiva de desestimular o ofensor a repetir a falta, sem constituir, de outro lado, enriquecimento indevido" (STJ, AgRg no AREsp 467.193/RJ, 3a T., Rel. Min. Sidnei Benetti, julg. 18.3.2014, DJe 28.3.2014).

${ }^{31}$ Para uma crítica à atribuição genérica de caráter punitivo à responsabilidade civil, v. MORAES, Maria Celina Bodin de. Punitive damages em sistemas civilistas: problemas e perspectivas. Na medida da pessoa humana: estudos de direito civil-constitucional. Rio de Janeiro: Renovar, 2010, pp. 371 e segs. e TEPEDINO, Gustavo; SCHREIBER, Anderson. As penas privadas no direito
} 
caráter punitivo teria impacto positivo na prevenção de danos, que é um dos objetivos do compliance. Nada obstante, há profundas distinções entre o compliance e a responsabilidade civil.

Em primeiro lugar, a função preventiva da responsabilidade civil costuma ser invocada após a efetiva ocorrência do dano, com o propósito imediato de majorar a verba indenizatória para além da extensão do dano o que, apenas mediatamente, serviria como desestímulo à produção de novos danos. ${ }^{32}$ Os mecanismos de compliance, a seu turno, se destinam imediatamente a uma autêntica prevenção de danos, atuando no sentido de mitigarem os riscos de infrações associados às atividades do agente econômico, ${ }^{33}$ sem prejuízo da importância do programa de compliancena reparação de danos e no retorno ao cenário de legalidade se não se tiver logrado evitar a infração. ${ }^{34}$

Em segundo lugar, a denominada função preventiva da responsabilidade civil depende da condenação judicial do agente a quem se imputam os danos a serem indenizados. Trata-se de consequência coercitivamente imposta pelo Estado. Os programas de compliance, ao revés, são modulados pelo agente econômico a partir das especificidades do seu negócio, estabelecendo sanções disciplinares dentro dos limites legalmente admitidos, bem como cooperando com o Poder Público sempre que necessário.

O compliance, ao contrário da responsabilidade civil, é sistema mais efetivamente vocacionado à prevenção de infrações e de danos, tendo por função primordial evitar a ocorrência de violações às normas legais aplicáveis, bem como ao Código de Ética próprio de cada pessoa jurídica. Precisamente nesse sentido, se afirma que o compliance "orienta-se, em verdade, pela finalidade preventiva, por meio da programação de uma série de condutas (condução de cumprimento) que estimulam a diminuição dos riscos da atividade”. ${ }^{35}$

brasileiro. In: SARMENTO, Daniel; GALDINO, Flavio (Orgs.). Direitos fundamentais: estudos em homenagem ao Professor Ricardo Lobo Torres. Rio de Janeiro: Renovar, 2006, p. 520.

${ }^{32}$ Cf. BARBOSA, Mafalda Miranda. Reflexões em torno da responsabilidade civil: teleologia e teleonomologia em debate. Boletim da Faculdade de Direito de Coimbra, vol. 81, 2005, p. 549.

${ }^{33}$ V. CABRERA, Michele Gironda. Compliancee imputação objetiva: criação de risco proibido. In: DAVID, Décio Franco (Org.). Compliance e direito penal. São Paulo: Atlas, 2015, p. 129; e CABETE, Eduardo Luiz Santos; NAHUR, Marcus Tadeu Maciel. "Criminal compliance" e ética empresarial: novos desafios do Direito Penal Econômico. Porto Alegre: Nuria Fabris, 2013, pp. 15 e segs.

${ }^{34}$ "Cumpre destacar o papel importante que tem assumido a implementação de programas de compliance nas grandes corporações e, em consequência, as investigações preventivas ou posteriores a fatos lesivos a empresa ou suspeitos em relação a entes públicos. Tais programas têm estimulado as empresas a desenvolver um ambiente mais sadio de práticas comerciais, bem como, se devidamente implementados, possibilitam boas ferramentas de investigação interna que podem apresentar importantes subsídios às investigações criminais posteriores ou concomitantes. Controle de contas de correio eletrônico, sistemas internos de trocas de mensagens, registros de acessos fisicos às suas unidades, gestão interna de processos, entre outros, fornecem inúmeros elementos importantíssimos para as investigações criminais, que não podem ser desprezados pelas autoridades públicas" (ANSELMO, Márcio Adriano. Compliance, Direito Penal e investigação criminal: uma análise à luz da ISO 19600 e 37001. Revista dos Tribunais, vol. 979, 2017, p. 63). 


\section{REPERCUSSÕES DO COMPLIANCE NO DIREITO PRIVADO}

Os tribunais têm gradativamente considerado a existência de programa sério de compliance como parâmetro interpretativo para a resolução de diversas questões envolvendo a atividade empresarial.

Nessa direção, a 4a Turma do STJ se utilizou do compliance como argumento adicional a justificar a impossibilidade de a apólice do seguro de responsabilidade civil de diretores e administradores cobrir a prática de atos dolosos. ${ }^{36}$

Em outro caso, no âmbito de ação movida por companhia com vistas à imposição de responsabilidade civil ao seu ex-diretor por alegada gestão temerária e exorbitância de suas funções, a 4a Turma do STJ entendeu que uma das razões ensejadoras da condenação consistia no fato de que, "como administrador principal da companhia tinha por obrigação implementar e fomentar boas práticas de governança corporativa, utilizando-se, para isso, de parâmetros/instrumentos legais e morais com vistas a aumentar o valor da sociedade, facilitar seu acesso ao capital e contribuir para a sua perenidade" ${ }^{37}$

Finalmente, a 36a Câmara Extraordinária de Direito Privado do Tribunal de Justiça do Estado de São Paulo entendeu que o descumprimento a regras de compliance seria fundamento legitimador da resilição unilateral do contrato de conta corrente por parte da instituição bancária. ${ }^{38}$

\footnotetext{
${ }^{35}$ SAAD-DINIZ, Eduardo; SILVEIRA, Renato Mello Jorge. Criminal compliance: limites revisitados da cooperação normativa quanto à lavagem de dinheiro. In: Compliance, direito penal e lei anticorrupção, São Paulo: Saraiva, 2015, p. 255.

36 "A apólice do seguro de RC D\&O não pode cobrir atos dolosos, principalmente se cometidos para favorecer a própria pessoa do administrador, o que evita forte redução do grau de diligência do gestor ou a assunção de riscos excessivos, a comprometer tanto a atividade de compliance da empresa quanto as boas práticas de governança corporativa. Aplicação dos arts. 757 e 762 do CC" (STJ, 3a T, REsp. 1.601.555/SP, Rel. Min. Ricardo Villas Bôas Cueva, julg. 14.2.2017).

${ }^{37}$ STJ, 4a T., REsp 1.475.706/SP, Rel. Min. Marco Buzzi, julg. 6.11.2014. Cumpre destacar a íntima relação entre as noções de compliance de governança corporativa, uma vez que as medidas características do compliance relacionam-se com a efetividade da governança corporativa adotada por cada entidade. A destacar tal relação, veja-se o excerto do Código de Governança Corporativa do Instituto Brasileiro de Governança Corporativa (IBGC): "Os agentes de governança têm responsabilidade em assegurar que toda a organização esteja em conformidade com os seus princípios e valores, refletidos em políticas, procedimentos e normas internas, e com as leis e os dispositivos regulatórios a que esteja submetida. A efetividade desse processo constitui o sistema de conformidade (compliance) da organização". V. tb. OLIVEIRA, José Carlos de; AGAPITO, Leonardo Simões; MIRANDA, Matheus de Alencar e. O modelo de "autorregulação regulada" e a teoria da captura: obstáculos à efetividade no combate à lavagem de dinheiro no Brasil. Quaestio Iuris, vol. 10, n. 1, 2017, p. 367; CASTRO, Julia Maria Gracia de. Apontamentos sobre a adoção das boas práticas de governança nas organizações do terceiro setor. Importância da adoção de um programa de compliance efetivo à luz da Lei n. 12.846/2015. Quaestio Iuris, vol. 9, n. 2, 2016, pp. 1015-1016.

${ }^{38}$ Do voto do Desembargador Relator extrai-se: "É certo que contratos de conta corrente, por serem destinados à longa duração, geram na parte a justa expectativa de continuidade. Desse modo, mostrar-se-ia ilícita a resilição de avenças dessa natureza de forma imotivada, pelo ferimento frontal à boa-fé objetiva, que deve ser respeitada de forma cogente, nos termos do artigo 422 do Código Civil. Ocorre, entretanto, que, no caso em tela, a conduta do réu foi líita, na medida em que a rescisão do contrato teve por justificativa o não atendimento às regras de compliance por parte da autora. (...) Com efeito, nestes autos pôde-se concluir que o encerramento da conta foi ocasionado por violação às regras de compliance pela autora. Afinal, programas de integridade em empresas dependem do envolvimento e da colaboração de sua alta administração para serem efetivos, o que, evidentemente, não
} 
Esses casos são meramente ilustrativos daquilo que parece constituir uma verdadeira tendência da expansão dos efeitos jurídicos do complianceno âmbito do direito privado. Afigura-se muito provável que tantos outros casos e aplicações venham a surgir, sendo ainda cedo para delimitar todas as repercussões da matéria na jurisprudência.

Oportuno destacar, ainda, a relevância do compliance no âmbito da responsabilidade civil. Vigora, atualmente, sistema dualista da responsabilidade civil, ${ }^{39} \mathrm{em}$ que convivem a cláusula geral de responsabilidade subjetiva (art. 186 do Código Civil) ${ }^{40}$ e a cláusula geral de responsabilidade objetiva (parágrafo único do art. 927 do Código Civil). ${ }^{41}$ Tais regimes se diferenciam fundamentalmente pela relevância da culpa na deflagração do dever de indenizar. ${ }^{42}$

A responsabilidade civil subjetiva tem como pressuposto do dever de reparar a verificação da culpa do agente causador do dano. A culpa é apreendida de maneira objetiva (culpa normativa), mediante a comparação da conduta do ofensor com standards objetivos de comportamento que sejam exigiveis à luz das circunstâncias do caso concreto.

De outra parte, a responsabilidade civil objetiva prescinde da demonstração de culpa do causador do dano. $\mathrm{O}$ agente não se exime do dever de reparar ao argumento de ter adotado os melhores padrões de diligência, uma vez que a deflagração da obrigação de indenizar não depende da análise da reprovabilidade da sua conduta.

Dessa forma, no âmbito da responsabilidade civil, o compliance só terá impacto, em regra, se esta for subjetiva, isto é, se for necessário aferir a reprovabilidade da conduta do ofensor. Com efeito, a existência de programa efetivo de compliance pode revelar expressiva diligência por parte da pessoa jurídica, a apontar para a ausência de divergência entre a sua conduta e o padrão que se lhe poderia exigir nas concretas circunstâncias em que o dano foi produzido.

ocorreu no âmbito da empresa autora" (TJSP, 36a C.E.D.P., Ap. Civ. 1013073-57.2016.8.26.0100, Rel. Des. Sérgio Rui, julg. 16.11.2017).

39 "A orientação foi absorvida pelo Código Civil Brasileiro de 2002, que, além de prever novas hipóteses específicas de responsabilidade objetiva, instituiu, no parágrafo único do seu artigo 927, uma cláusula geral de responsabilidade objetiva para atividades de risco. Consolida-se, assim, o modelo dualista que já se delineava no sistema anterior, convivendo lado a lado a norma geral de responsabilidade civil subjetiva, do atual art. 186, que tem como fonte o ato ilícito, e as normas reguladoras da responsabilidade objetiva para determinadas atividades, informadas por fonte legislativa específica e agora também pela cláusula geral contida na nova codificação civil" (TEPEDINO, Gustavo. A evolução da responsabilidade civil no direito brasileiro e suas controvérsias na atividade estatal. Temas de direito civil. 4. ed. Rio de Janeiro: Renovar, 2008, p. 205).

${ }^{40}$ Art. 186 do Código Civil: "Aquele que, por ação ou omissão voluntária, negligência ou imprudência, violar direito e causar dano a outrem, ainda que exclusivamente moral, comete ato ilícito". V. tb. o caput do art. 927 do Código Civil, in verbis: "Aquele que, por ato ilícito (arts. 186 e 187), causar dano a outrem, fica obrigado a repará-lo".

${ }^{41}$ Art. 927, parágrafo único, do Código Civil: "Haverá obrigação de reparar o dano, independentemente de culpa, nos casos especificados em lei, ou quando a atividade normalmente desenvolvida pelo autor do dano implicar, por sua natureza, risco para os direitos de outrem".

${ }^{42}$ V., por todos, PEREIRA, Caio Mário da Silva. Responsabilidade civil. 11 . ed. Atual. Gustavo Tepedino. Rio de Janeiro: Forense, 2016, pp. 19 ess. 


\section{INFLUXOS DOS PROGRAMAS DE COMPLIANCE SOBRE A RESPONSABILIZAÇÃO ADMINISTRATIVA DAS PESSOAS JURÍDICAS: ESTÍMULO AOS PROGRAMAS DE INTEGRIDADE COMO MANIFESTAÇÃO DA FUNÇÃO PROMOCIONAL DO DIREITO}

A referência, pela legislação brasileira, a programas de compliance no âmbito da imposição de sanções administrativas às pessoas jurídicas traduz manifestação da mudança paradigmática da função meramente repressiva para a função promocional do direito. Independentemente da teoria que se adote para a responsabilização administrativa da pessoa jurídica e das consequências que decorrem de cada uma delas na aplicação das sanções, o compliance desempenha importante papel em qualquer caso e, nesse sentido, sua adoção pelas corporações é incentivada.

Basicamente, há dois entendimentos acerca da responsabilidade administrativa da pessoa jurídica. À exposição sintética de tais proposições teóricas não subjaz qualquer propósito de tratamento exaustivo da matéria, mas tão somente o intuito de ressaltar a relevância assumida pelo compliance para fins de implementação de políticas públicas de estímulos a condutas socialmente desejadas.

De uma parte, sustenta-se a responsabilização da pessoa jurídica por fato próprio, isto é, que não decorra da sua vinculação automática a ato praticado por seu administrador ou representante, mas que traduza fato efetivamente imputável a um problema operacional interno da pessoa jurídica. Assim, o fundamento para a punição não seria a vinculação da pessoa jurídica por ato praticado por seu administrador ou representante, mas sim a constatação de uma falha de organização que houvesse tornado possível a prática do ilícito pela pessoa natural em nome da pessoa jurídica. ${ }^{43}$ Tal linha de entendimento pugna pela impossibilidade de imposição de penalidade ao ente coletivo sem a demonstração da sua própria culpabilidade, de maneira autônoma em relação à culpabilidade de cada um dos administradores ou colaboradores que pratiquem ilícitos corporativos.

Em contraposição, defende-se a responsabilização automática da pessoa jurídica por fato de seus administradores ou representantes no interesse ou em benefício da pessoa jurídica, sem a necessidade de

\footnotetext{
43 "Diante da problemática anunciada - como justificar a responsabilidade da pessoa jurídica para fins punitivos -, há basicamente duas opções: ou se pune a pessoa jurídica por ato próprio ou se pune a pessoa jurídica por fato de seus administradores ou representantes. $\mathrm{Na}$ primeira hipótese, o fundamento para a punição não é a imputação à pessoa jurídica de um ato de administrador ou de representante, mas sim a constatação de uma falha de organização que possibilitou que as pessoas naturais em comento praticassem aquele ilícito em nome da pessoa jurídica. Assim, busca-se criar um sistema específico de culpabilidade da pessoa jurídica, no qual existiria responsabilidade por fato próprio, em razão de vício organizativo consistente na ausência de prevenção da conduta ilícita" (FRAZÃO, Ana. Programas de compliance e critérios de responsabilização de pessoas jurídicas por ilícitos administrativos, cit., p. 26). Da mesma autora, v., ainda, FRAZÃO, Ana. Responsabilidade de pessoas jurídicas por atos de corrupção: reflexão sobre os critérios de imputação. In: FORTINI, Cristiana (Coord.). Corrupção e seus múltiplos enfoques jurídicos. Belo Horizonte: Fórum, 2018, p. 36
} 
realização de um juízo valorativo específico para se definir a culpabilidade do ente coletivo. ${ }^{44}$ Tal orientação corresponde ao sistema de responsabilidade denominado, pela tradição jurídica anglo-saxã, de vicarious liability, cuja base "é o princípio 'let the superior answer' desde que o representante (agent) esteja agindo em nome de representado (principal) e em benefício deste". ${ }^{45}$

A rigor, as pessoas jurídicas manifestam a sua vontade e atuam por meio dos seus representantes, de modo que as ações e omissões destes podem justificar a responsabilidade daquelas, sem prejuízo da responsabilidade pessoal destes. Não quer isso dizer, contudo, que as pessoas jurídicas devem responder, no campo punitivo, sempre e incondicionalmente, por todas as ações de seus administradores ou representantes. ${ }^{46}$ Precisamente em razão do seu caráter sancionador, a imposição de penalidades não poderia prescindir de juízo valorativo sobre a culpabilidade do ente coletivo. ${ }^{47}$

Para o primeiro entendimento, o compliance poderia até mesmo isentar a responsabilidade administrativa da pessoa jurídica. Já para o segundo entendimento, o compliance no máximo poderia servir de atenuante na dosimetria da pena. ${ }^{48}$ Em meio à dualidade de cenários possíveis, o legislador brasileiro adotou, na

\footnotetext{
44 "Feitas essas observações, pode-se afirmar que o sistema de heterorresponsabilidade - ou vicarial, de transferência, por ricochete, por empréstimo - é aquele 'se imputa transferido à empresa todo ato cometido por um agente seu, no exercício de sua atividade, com a intenção de favorecê-la'" (SARCEDO, Leandro. Compliance e responsabilidade penal da pessoa jurídica, cit., p. 135). V., ainda, LEITE, Maurício Silva; NOBRE, Eduardo Maffia Queiroz. Responsabilidade solidária por atos de corrupção. Revista dos Tribunais, n. 947, set./2014, p. 317.

${ }^{45}$ FRAZÃO, Ana. Programas de compliance e critérios de responsabilização de pessoas jurídicas por ilícitos administrativos, cit., p. 30.

${ }^{46}$ FRAZÃO, Ana. Implementação de programa de compliance deve atenuar penalidades a empresas. CONJUR. Acesso em 01.04.2018.

47 “(...) ainda que se cogite possível a responsabilidade objetiva para efeitos de imputação dos atos de determinados órgãos, administradores ou representantes da pessoa jurídica, não seria justificável que as pessoas jurídicas sejam punidas por atos que não sejam considerados ilícitos ou reprováveis. Tal discussão tem inequívoca natureza constitucional, em estreita conexão com os princípios da antijuridicidade, da culpabilidade e da individualização da pena, que confluem para a conclusão de que a reprovabilidade da conduta deve ser a medida da sanção. Assim, não havendo reprovabilidade da conduta, perde-se até mesmo o parâmetro fundamental da dosimetria da pena" (FRAZÃO, Ana. Programas de compliance e critérios de responsabilização de pessoas jurídicas por ilícitos administrativos, cit., pp. 37-38). A autora sustenta, ainda, a similitude funcional entre o regime sancionatório criminal e aquele administrativo: "Dessa maneira, é forçosa a conclusão de que, diante das inegáveis semelhanças entre o Direito Administrativo Sancionador e o Direito Penal, faz-se necessária uma base principiológica comum entre os dois, ainda que, como aponta Alejandro Nieto, esta base precise ser matizada e adaptada para ser aplicada ao primeiro, em face de sua maior flexibilidade. Entretanto, a mencionada matização não pode comprometer o pressuposto essencial do exercício de qualquer poder punitivo por parte do Estado: a necessária culpabilidade, já que a sanção é, inclusive, a medida da reprovabilidade da conduta. Logo, apenas se cogita de delito quando estão presentes os elementos da tipicidade, da antijuridicidade e da culpabilidade, não havendo qualquer razão para afastar tais conclusões em relação ao ilícito administrativo" (Ibid., pp. 25-26). V. tb. SARCEDO, Leandro. Compliance e responsabilidade penal da pessoa jurídica, cit., p. 264.

${ }^{48}$ No que tange à relevância do compliance no âmbito da responsabilização por fato próprio, afirma-se: "Nesse contexto, é significativo o papel do compliance, já que a existência de um bom programa pode afastar o defeito de organização e, consequentemente, a responsabilidade da pessoa jurídica. De fato, o papel da autorregulação, muito mais do que mero instrumento aditivo de dever de garantia, é o de fundamentar a responsabilidade da pessoa jurídica no âmbito punitivo, conclusão que não se restringe necessariamente ao âmbito penal. Se não há defeito de organização, responderá na esfera punitiva somente a pessoa natural, sem prejuízo de que a pessoa jurídica responda, de forma objetiva e solidária, pelo ressarcimento de eventuais danos no
} 
Lei Anticorrupção, o segundo entendimento, de maneira que a existência de compliance não tem o condão de afastar a condenação da pessoa jurídica, mas apenas serve como possível atenuante da penalidade que lhe será imposta. $^{49}$

Sem embargo dessa discussão, ressalte-se que a interferência do compliance na dosimetria da pena já consubstancia estímulo à sua adoção pelas pessoas jurídicas. Somem-se a isso as expressivas e crescentes perspectivas de utilização de padrões de compliance pelo legislador, o que serve de motivação à implementação de medidas tendencialmente mais aptas à consolidação de um cenário pautado pela ética empresarial e pelo respeito à legalidade. ${ }^{50}$ Eis o potencial do compliance como mecanismo de atuação da função promocional do direito. ${ }^{51}$

A perspectiva promocional passa pela criação de normas que incentivam condutas, estabelecendo vantagens para aqueles que implementam o comportamento desejado. Desse modo, afigura-se positiva a tendência contemporânea de absorção cada vez maior do compliance, pelo direito positivo, como ponto de referência para o estímulo à adoção de programas destinados à consolidação de uma cultura corporativa de respeito à legalidade.

âmbito da responsabilidade civil" (FRAZÃO, Ana. Programas de compliance e critérios de responsabilização de pessoas jurídicas por ilícitos administrativos, cit., p. 29).

${ }^{49}$ V. novamente art. $7^{\circ}$ da Lei 12.846/2013: "Serão levados em consideração na aplicação das sanções: VIII - a existência de mecanismos e procedimentos internos de integridade, auditoria e incentivo à denúncia de irregularidades e a aplicação efetiva de códigos de ética e de conduta no âmbito da pessoa jurídica (...)”. A Lei Antitruste não aduz expressamente ao compliance como atenuante da pena. Nada obstante, consoante se ressaltou, o Guia Programas de Compliance do CADE estabelece que a adoção de um programa de compliance robusto pode ser considerada (i) uma evidência de boa-fé e como uma atenuante no cálculo da multa, reduzindo-a, ou como (ii) um critério a ser considerado quando do cálculo da contribuição pecuniária, em eventual TCC a ser assinado pela organização, que poderia levar o percentual de desconto ao máximo permitido. Para uma análise do sistema de responsabilidade consagrado pela Lei Anticorrupção, v., ainda, HAGE SOBRINHO, Jorge. Lei 12.846/2013: Lei da Empresa Limpa. Revista dos Tribunais, vol. 947, set./2014, item 5.

50 "A importância dos referidos programas [de compliance] decorre do fato de que, como defendem Riley e Sokol, o enforcement tradicional, por si só, não é capaz de produzir o comprometimento com a lei que os programas de compliance pretendem construir, na medida em que a aplicação de sanções não consegue alcançar a percepção de moralidade do comportamento que está sendo regulado ao meramente colocar um preço no descumprimento das normas" (FRAZÃO, Ana. Programas de compliancee critérios de responsabilização de pessoas jurídicas por ilícitos administrativos, cit., p. 43).

51 "Em poucas palavras, é possível distinguir, de modo útil, um ordenamento protetivo-repressivo de um promocional com a afirmação de que, ao primeiro, interessam, sobretudo, os comportamentos socialmente não desejados, sendo seu fim prećípuo impedir o máximo possível a sua prática; ao segundo, interessam, principalmente, os comportamentos socialmente desejáveis, sendo seu fim levar a realização destes até mesmo aos recalcitrantes" (BOBBIO, Norberto. A função promocional do direito. Da estrutura a função: novos estudos de teoria do direito. Trad. Daniela Beccaccia Versiani. Barueri: Manole, 2007, p. 15). Pertinente, ainda, a lição de Gustavo Tepedino: "(...) o legislador, para além de coibir comportamentos indesejados — os atos ilícitos —, em atuação repressiva, age através de leis de incentivo, propõe vantagens ao destinatário da norma jurídica, quer mediante financiamentos subsidiados, quer mediante a redução de impostos, taxas ou tarifas públicas; para com isso atingir objetivos propostos por tais leis, as chamadas leis-incentivo, com finalidades específicas. Revela-se, então, o novo papel assumido pelo legislador, argutamente identificado por Noberto Bobbio como 'a função promocional do direito', consubstanciada exatamente na promoção de certas atividades ou comportamentos, almejados pelo legislador, através de normas que incentivam os destinatários, 


\section{CONSIDERAÇÕES CONCLUSIVAS}

As precedentes considerações buscaram expor, inicialmente, que se podem identificar duas configurações explícitas do compliance no direito brasileiro: (i) prática incentivada por meio da previsão legal de consequências favoráveis ( $v$ g. dosimetria da pena) ou (ii) obrigação legal em sentido estrito (como no caso da imposição, pela legislação federal, da obrigatoriedade de as empresas estatais adotarem programas de compliance). Ao lado dessas configurações, a análise da jurisprudência nacional revela um gradual crescimento da utilização da noção de compliance como parâmetro interpretativo para a compreensão e a resolução de questões variadas atinentes à atividade empresarial.

Pôde-se destacar, ainda, que mesmo no âmbito das hipóteses em que o compliance constitui objeto de autêntica obrigação legal imposta aos agentes econômicos, há expressiva margem de autonomia para a conformação do programa de integridade a ser adotado por cada pessoa jurídica. Isso porque não há um único modelo de compliance que possa ser adotado indistintamente por todas as pessoas jurídicas. Justamente por se tratar de sistema de prevenção de riscos e de respeito à legalidade, precisa se adequar à concreta atividade empreendida pela corporação e aos riscos e à regulamentação que lhe são próprios.

Verificou-se, ademais, o importante papel que pode ser desempenhado pelo compliance no direito privado, notadamente no campo da responsabilidade civil subjetiva. Analisaram-se, ainda, os principais influxos do compliance na disciplina da responsabilização administrativa das pessoas jurídicas. No Brasil, a existência de compliance não tem o condão de afastar a responsabilização administrativa das pessoas jurídicas na seara anticorrupção e antitruste, mas serve como possível atenuante na dosimetria da pena. ${ }^{52}$

Além disso, o compliance também apresenta impactos positivos para a imagem e a inserção da pessoa jurídica no mercado, na medida em que a adoção de programas de integridade desperta confiança nos seus parceiros comerciais, consumidores, funcionários, colaboradores e todos aqueles que com ela travam algum tipo de relação jurídica.

Portanto, seja por imposição legal, seja por incentivo normativo, seja por estímulo concorrencial e negocial, o cenário contemporâneo revela irreversível tendência de expansão e consolidação da relevância dos programas de compliance no ambiente corporativo brasileiro, que estimulam a ética e o respeito à legalidade,

mediante o oferecimento de vantagens individuais" (TEPEDINO, Gustavo. Premissas metodológicas para a constitucionalização do direito civil. Temas de direito civil. 4. Ed. Rio de Janeiro: Renovar, 2008, pp. 9-11).

52 "No caso brasileiro, tanto na seara anticorrupção quanto na seara antitruste, um bom programa de compliancejamais poderá afastar a responsabilidade da pessoa jurídica, podendo ser, na melhor das hipóteses, uma atenuante a ser considerada na dosimetria” (FRAZÃO, Ana. Dever de diligência, cit.). V. tb. FRAZÃO, Ana. Programas de compliance e critérios de responsabilização de pessoas jurídicas por ilícitos administrativos, cit., pp. 34-36. 
prevenindo a ocorrência de infrações à ordem legal.

\begin{abstract}
The central scope of this study is to investigate of the legal effects of compliance in Brazilian law. In this sense, it examines the main judicial decisions and the main rules that deal with compliance, either as an incentive or as a legal order. In addition, it analyzes the growth of the importance attributed by economic agents to compliance due to the advantages that it provides for the insertion and valuation of the company in the market. The text also examines the treatment of the matter by the courts, which have increasingly used the notion of compliance as an interpretive parameter for solving the most varied issues involving business activity. Finally, it investigates the repercussion of the adoption of integrity programs within the scope of administrative sanctions applicable to legal entities.
\end{abstract}

Keywords: Compliance; Integrity programs; Self-regulation; Self-monitoring; Administrative liability of legal entities.

\title{
REFERÊNCIAS BIBLIOGRÁFICAS
}

ANSELMO, Márcio Adriano. Compliance, Direito Penal e investigação criminal: uma análise à luz da ISO 19600 e 37001. Revista dos Tribunais, vol. 979, 2017.

AUGUSTO, Naiara Czarnobai, Compliance corporativo. In: JOTA. Acesso em 01.04.2018.

BALTAZARJUNIOR, José Paulo. Sigilo bancário e privacidade. Porto Alegre: Livraria do Advogado, 2005.

BARBOSA, Mafalda Miranda. Reflexões em torno da responsabilidade civil: teleologia e teleonomologia em debate. Boletim da Faculdade de Direito de Coimbra, vol. 81, 2005.

BLOK, Marcella. Compliance e governança corporativa. Rio de Janeiro: Freitas Bastos, 2018.

CABETE, Eduardo Luiz Santos; NAHUR, Marcus Tadeu Maciel. "Criminal compliance” e ética empresarial: 
novos desafios do Direito Penal Econômico. Porto Alegre: Nuria Fabris, 2013.

CABRERA, Michele Gironda. Compliance e imputação objetiva: criação de risco proibido. In: DAVID, Décio Franco (Org.). Compliance e direito penal. São Paulo: Atlas, 2015.

CASTRO, Julia Maria Gracia de. Apontamentos sobre a adoção das boas práticas de governança nas organizações do terceiro setor. Importância da adoção de um programa de compliance efetivo à luz da Lei n. 12.846/2015. Quaestio Iuris, vol. 9, n. 2, 2016.

COSTA, Helena Regina Lobo da; ARAÚJO, Marina Pinhão Coelho. compliance e o julgamento da APN 470. Revista Brasileira de Ciências Criminais, vol. 106, 2014. Acesso pela Revista dos Tribunais Online, em 02.04.2018. FRAZÃO, Ana. Cartilha sobre Compliance. No prelo.

FRAZÃO, Ana. Dever de diligência: novas perspectivas em face de programas de compliance e de atingimento de metas. In: JOTA. Acesso em 01.04.2018.

Implementação de programa de compliance deve atenuar penalidades a empresas. CONJUR. Acesso em 01.04.2018.

Programas de compliance e critérios de responsabilização de pessoas jurídicas por ilícitos administrativos. In: ROSSETTI, Maristela Abla; PITTA, Andre Grunspun (Coords.). Governança corporativa: avanços e retrocessos. São Paulo: Quartier Latin, 2017.

Responsabilidade de pessoas jurídicas por atos de corrupção: reflexão sobre os critérios de imputação. In: FORTINI, Cristiana (Coord.). Corrupção e seus múltiplos enfoques jurídicos. Belo Horizonte: Fórum, 2018.

GUARAGNI, Fábio André. Princípio da confiança no direito penal como argumento em favor de órgãos empresariais em posição de comando e compliance: relações e possibilidades. In: GUARAGNI, Fábio André; BUSATO, Paulo César (Coords.). Compliance e direito penal. São Paulo: Atlas, 2015.

GUARAGNI, Fábio André; MARIA SOBRINHO, Fernando Martins. Compliance e crimes culposos: a categoria do risco proibido como ponto de um "encontro marcado". Quaestio Iuris, vol. 9, n. 1, 2016.

HAGE SOBRINHO, Jorge. Lei 12.846/2013: Lei da Empresa Limpa. Revista dos Tribunais, vol. 947, set./2014. 
HENNING, Peter J. Be Careful What You Wish For: Thoughts on a Compliance Defense Under the Foreign Corrupt Practices Act. Ohio State Law Journal, vol. 73, 2012.

KRAWIEC, Kimberly D. Cosmetic Compliance and the Failure of Negotiated Governance. Washington University Law Quarterly, vol. 81, 2003.

LEITE, Maurício Silva; NOBRE, Eduardo Maffia Queiroz. Responsabilidade solidária por atos de corrupção. Revista dos Tribunais, n. 947, set./2014.

MARTINEZ, Maria Beatriz. Programas de compliance e a defesa da concorrência: perspectivas para o Brasil. Revista do IBRAC - Direito da Concorrência, Consumo e Comércio Internacional, vol. 12, jan./2005.

MORAES, Maria Celina Bodin de. Punitive damages em sistemas civilistas: problemas e perspectivas. Na medida da pessoa humana: estudos de direito civil-constitucional. Rio de Janeiro: Renovar, 2010.

OLIVEIRA, José Carlos de; AGAPITO, Leonardo Simões; MIRANDA, Matheus de Alencar e. O modelo de "autorregulação regulada" e a teoria da captura: obstáculos à efetividade no combate à lavagem de dinheiro no Brasil. Quaestio Iuris, vol. 10, n. 1, 2017.

PEREIRA, Caio Mário da Silva. Responsabilidade civil. 11. ed. Atual. Gustavo Tepedino. Rio de Janeiro: Forense, 2016.

RILEY, Anne; SOKOL, D. Daniel. Rethinkg Compliance. Journal of Antitrust Enforcement, vol. 3, n. 1, abr./2015. RIOS, Rodrigo Sánchez; ANTONIETTO, Caio. Criminal compliance - prevenção e minimização de riscos na gestão da atividade empresarial. Revista Brasileira de Ciências Criminais, vol. 114, mai.-jun./2015.

SAAD-DINIZ, Eduardo; SILVEIRA, Renato Mello Jorge. Criminal compliance: limites revisitados da cooperação normativa quanto à lavagem de dinheiro. In: Compliance, direito penal e lei anticorrupção, São Paulo: Saraiva, 2015.

SARCEDO, Leandro. Compliance e responsabilidade penal da pessoa jurídica: construção de um novo modelo 
de imputação, baseado na culpabilidade corporativa. Tese de doutorado. Universidade do Estado de São Paulo. São Paulo, 2014.

SILVEIRA, Renato de Mello Jorge. Compliance e direito penal na era pós-Lava Jato. Revista dos Tribunais, vol. 979, mai./2017.

SOUZA, Artur de Brito Gueiros; JAPIASSÚ, Carlos Eduardo Adriano. Criminologia e delinquência empresarial: da cultura criminógena à cultura do compliance. Quaestio Iuris, vol. 19, n. 2, 2017.

STUCKE, Maurice E. In Search of Effective Ethics \& Compliance Programs. The Journal of Corporation Law, vol. 39, 2014.

TEPEDINO, Gustavo. A evolução da responsabilidade civil no direito brasileiro e suas controvérsias na atividade estatal. Temas de direito civil. 4. ed. Rio de Janeiro: Renovar, 2008.

Premissas metodológicas para a constitucionalização do direito civil. Temas de direito civil. 4. Ed. Rio de Janeiro: Renovar, 2008.

TEPEDINO, Gustavo; SCHREIBER, Anderson. As penas privadas no direito brasileiro. In: SARMENTO, Daniel; GALDINO, Flavio (Orgs.). Direitos fundamentais: estudos em homenagem ao Professor Ricardo Lobo Torres. Rio de Janeiro: Renovar, 2006.

WOUTERS, Jan; RYNGAERT, Cedric; CLOOTS, Ann Sofie. The International Legal Framework Against Corruption: Achievements and Challenges. Melbourne Journal of International Law, vol. 14, 2013.

Trabalho enviado em 22 de abril de 2018

Aceito em 03 de setembro de 2018 